\title{
UPAYA MENINGKATKAN PRESTASI BELAJAR PKN MELALUI METODE PEMBELAJARAN KOOPERATIF MODEL STAD PADA SISWA KELAS V SDN 167645 KOTA TEBING TINGGI
}

\author{
Asmaliah Pane \\ Surel: brpaneasmaliah@gmail.com
}

\begin{abstract}
ABSTRAK
Penelitian ini menggunakan penelitian tindakan (action research) sebanyak tiga siklus. Sasaran penelitian ini adalah siswa kelas V SDN 167645 Kota Tebing TInggi Tahun Ajaran 2015/2016. Data yang diperoleh berupa hasil tes formatif, lembar observasi kegiatan belajar mengajar. Berdasarkan hasil analisis didapatkan bahwa prestasi belajar siswa mengalami peningkatan dari siklus I sampai siklus III, yaitu siklus I $(68,42 \%)$, siklus II (81,58\%), siklus III $(94,74 \%)$. Simpulan dari penelitian ini adalah metode pembelajaran kooperatif berpengaruh positif terhadap prestasi dan motivasi belajar siswa kelas V SDN 167645 Kota Tebing TInggi serta model pembelajaran ini dapat digunakan sebagai salah satu alternatif pembelajaran PKn.
\end{abstract}

Kata Kunci : Model Pembelajaran STAD, Motivasi, Prestasi

\section{PENDAHULUAN}

Mengajar adalah membimbing siswa sehingga ia mampu belajar. Aktifitas siswa sangat diperlukan dalam kegiatan belajar-mengajar sehingga siswa yang seharusnya banyak aktif, sebab siswa sebagai subyek didik adalah yang merencanakan, dan ia sendiri yang melaksanakan belajar. Pada kenyataan, di sekolah-sekolah seringkali guru yang aktif, sehingga siswa tidak diberi kesempatan untuk aktif.

Pembelajaran kooperatif lebih menekankan interaksi antar siswa. Dari sini siswa akan melakukan komunikasi aktif dengan sesama temannya. Dengan komunikasi tersebut diharapkan siswa dapat menguasai materi pelajaran dengan mudah karena "siswa lebih mudah memahami penjelasan dari kawannya dibanding penjelasan dari guru, karena taraf pengetahuan serta pemikiran mereka lebih sejalan dan sepadan". (Sulaiman dalam Wahyuni 2001: 2).

Berdasarkan paparan tersebut di atas, maka peneliti ingin mencoba melakukan penelitian dengan judul "Upaya Meningkatkan Prestasi Belajar PKn Melalui Metode Pembelajaran Kooperatif Model STAD (Student Teams Achievement Division) pada Siswa Kelas V SDN 167645 Kota Tebing Tinggi Tahun Ajaran 2015/2016.

Guru SD Negeri 167645 Kota Tebing Tinggi 


\section{METODE PENELITIAN}

Penelitian ini dilaksanakan pada bulan Februari-April 2016. Subjek penelitian adalah siswa kelas V SDN 167645 Kota Tebing Tinggi Tahun Ajaran 2015/2016.

Penelitian ini menggunakan model penelitian tindakan dari Kemmis dan Taggart (dalam Arikunto, 2002: 83) yaitu berbentuk siklus. Setiap siklus meliputi planning (rencana), action (tindakan), observation (pengamatan), dan reflection (refleksi).

Alat pengumpul data dalam penelitian ini adalah tes dan observasi.

Pada penelitian ini menggunakan teknik analisis dekriptif kualitatif yaitu suatu metode penelitian yang bersifat menggambarkan kenyataan atau fakta sesuai dengan data yang diperoleh.

Peneliti melakukan penjumlahan nilai rata-rata tes formatif dengan rumus:

$$
\begin{aligned}
& \overline{\mathrm{X}}=\frac{\sum x}{\sum \mathrm{N}} \\
\mathrm{X} & =\text { Nilai rata-rata } \\
\sum \mathrm{X} & =\text { Jumlah semua nilai siswa } \\
\sum \mathrm{N} & =\text { Jumlah siswa }
\end{aligned}
$$

Untuk menghitung persentase ketuntasan belajar digunakan rumus sebagai berikut:

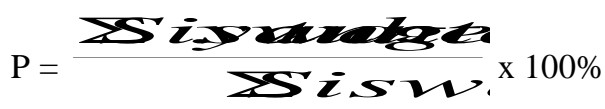

Untuk menghitung lembar observasi pengelolaan metode pembelajaran kooperatif model STAD digunakan rumus sebagai berikut :

$$
\overline{\mathrm{X}}=\frac{P 1+P 2}{2}
$$

$\mathrm{P} 1=$ Pengamat 1 dan

$\mathrm{P} 2=$ Pengamat 2

Untuk menghitung lembar observasi aktifitas guru dan siswa digunakan rumus sebagai berikut :

$$
\begin{gathered}
\%=\frac{\bar{x}}{\sum x} \times 100 \% \text { dengan } \\
\mathrm{X}=\frac{\text { Jumahhasilpengamatan }}{\text { Jumlahpengamatan }}=\frac{P 1+P 2}{2}
\end{gathered}
$$

Dimana :

$\%=$ Presentase pengamatan

$\mathrm{X}=$ Rata-rata

$\sum \mathrm{x}=$ Jumlah rata-rata

$\mathrm{P} 1=$ Pengamat 1

$\mathrm{P} 2=$ Pengamat 2

\section{HASIL DAN PEMBAHASAN}

Siklus I dilakasanakan pada tanggal 13 Februari 2016 di kelas V SDN 167645 Kota Tebing Tinggi dengan jumlah siswa 38 siswa. Pelaksanaan metode pembelajaran kooperatif model STAD melalui tahapan sebagai berikut:

(1) Pelaksanaan pembelajaran,

(2) Diskusi kelompok,

(3) Tes,

(4) Penghargaan kelompok,

(5) Menentukan nilai individual dan kelompok. 


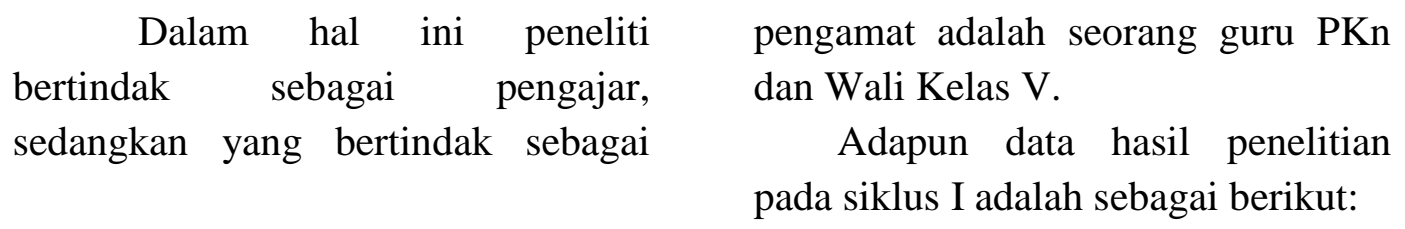

Tabel 4.1 Pengelolaan Pembelajaran Pada Siklus I

\begin{tabular}{|c|c|c|c|c|}
\hline \multirow{2}{*}{ No } & \multirow{2}{*}{ Aspek yang diamati } & \multicolumn{2}{|c|}{ Penilaian } & \multirow{2}{*}{$\begin{array}{l}\text { Rata- } \\
\text { rata }\end{array}$} \\
\hline & & P1 & P2 & \\
\hline \multirow{3}{*}{ I } & $\begin{array}{l}\text { Pengamatan KBM } \\
\text { A. Pendahuluan } \\
\text { - Memotivasi siswa } \\
\text { - Menyampaikan tujuan pembelajaran } \\
\text { - Menghubungkan dengan pelajaran sebelumnya } \\
\text { - } \quad \text { Mengatur siswa dalam kelompok-kelompok belajar }\end{array}$ & $\begin{array}{l}2 \\
2\end{array}$ & $\begin{array}{l}2 \\
2\end{array}$ & $\begin{array}{l}2 \\
2\end{array}$ \\
\hline & $\begin{array}{l}\text { B. Kegiatan inti } \\
\text { - Mempresentasikan langkah metode pembelajaran } \\
\text { kooperatif } \\
\text { - Membimbing siswa melakukan kegiatan } \\
\text { - Melatih keterampilan kooperatif } \\
\text { - Mengawasi setiap kelompok secara bergiliran } \\
\text { - Memberi bantuan pada kelompok yang mengalami } \\
\text { kesulitan }\end{array}$ & $\begin{array}{l}3 \\
3\end{array}$ & $\begin{array}{l}3 \\
3 \\
3 \\
3\end{array}$ & $\begin{array}{l}3 \\
3 \\
3\end{array}$ \\
\hline & $\begin{array}{l}\text { C. } \\
\text { Penutup } \\
\text { 1. } \quad \text { Membimbing siswa membuat rangkuman } \\
\text { 2. } \quad \text { Memberikan evaluasi }\end{array}$ & $\begin{array}{l}3 \\
3\end{array}$ & $\begin{array}{l}3 \\
3 \\
\end{array}$ & $\begin{array}{l}3 \\
3\end{array}$ \\
\hline II & Pengelolaan Waktu & 2 & 2 & 2 \\
\hline \multirow[t]{2}{*}{ III } & \begin{tabular}{ll}
\multicolumn{2}{l}{ Antusiasme Kelas } \\
1. & Siswa antusias \\
2. & Guru antisias \\
\end{tabular} & $\begin{array}{l}2 \\
3 \\
\end{array}$ & $\begin{array}{l}2 \\
3 \\
\end{array}$ & $\begin{array}{l}2 \\
3 \\
\end{array}$ \\
\hline & Jumlah & 32 & 32 & 32 \\
\hline
\end{tabular}

\section{Keterangan :}

1. Tidak Baik

2. Kurang Baik

3. Cukup Baik

4. Baik

Berdasarkan tabel di atas aspek yang mendapatkan kriteria kurang baik adalah memotivasi siswa, menyampaikan tujuan pembelajaran, pengelolaan waktu, dan siswa antusias. Keempat aspek yang mendapat nilai kurang baik di atas, merupakan suatu kelemahan yang terjadi pada siklus I dan akan dijadikan bahan kajian untuk refleksi dan revisi yang akan dilakukan pada siklus II.

Hasil observasi berikutnya adalah aktivitas guru dan siswa seperti pada tabel berikut : 
Tabel 4.2 Pengelolaan Pembelajaran Pada Siklus I

\begin{tabular}{|c|l|c|}
\hline No & Aktivitas Guru yang diamati & Presentase \\
\hline 1 & Menyampaikan tujuan & 5,0 \\
2 & Memotivasi siswa & 8,3 \\
3 & Mengkaitkan dengan pelajaran sebelumnya & 8,3 \\
4 & Menyampaikan materi/ langkah-langkah/ strategi & 6,7 \\
5 & Menjelaskan materi yang sulit & 13,3 \\
6 & Membimbing dan mengamati siswa dalam menemukan & 21,7 \\
7 & konsep & 10,0 \\
8 & Meminta siswa menyajikan dan mendiskusikan hasil kegiatan & 18,3 \\
9 & Memberikan umpan balik & 8,3 \\
\hline No & Membimbing siswa merangkum pelajaran & Presentase \\
\hline 1 & Mendengarkan/ memperhatikan penjelasan guru & 22,5 \\
2 & Membaca buku & 11,5 \\
3 & Bekerja dengan sesama anggota kelompok & 18,7 \\
4 & Diskusi antar siswa/ antara siswa dengan guru & 14,4 \\
5 & Menyajikan hasil pembelajaran & 2,9 \\
6 & Menyajikan/ menanggapi pertanyaan/ ide & 5,2 \\
7 & Menulis yang relevan dengan KBM & 8,9 \\
8 & Merangkum pembelajaran & 6,9 \\
9 & Mengerjakan tes evaluasi & 8,9 \\
\hline
\end{tabular}

Berdasarkan tabel di atas tampak bahwa aktivitas guru yang paling dominan pada siklus I adalah membimbing dan mengamati siswa dalam menemukan konsep, yaitu 21,7\%. Aktivitas lain yang persentasinya cukup besar adalah memberi umpan balik, tanya jawab dan menjelaskan materi yang sulit yaitu masing-masing sebesar 13,3\%. Sedangkan aktivitas siswa yang paling dominan adalah mengerjakan/ memperhatikan penjelasan guru yaitu 22,5\%. Aktivitas lain yang persentasinya cukup besar adalah bekerja dengan sesama anggota kelompok, diskusi antara siswa/ antara siswa dengan guru, dan membaca buku yaitu masing-masing $18,7 \%, 14,4 \%$ dan $11,5 \%$.
Pada siklus I, secara garis besar kegiatan belajar mengajar dengan metode pembelajaran kooperatif model STAD sudah dilaksanakan dengan baik, walaupun peran guru masih cukup dominan untuk memberikan penjelasan dan arahan, karena model tersebut masih dirasakan baru oleh siswa.

Berikut adalah rekapitulasi hasil tes formatif siswa.

Tabel 4.3. Rekapitulasi Hasil Tes Formatif Siswa Pada Siklus I

\begin{tabular}{|l|l|c|}
\hline No & \multicolumn{1}{|c|}{ Uraian } & $\begin{array}{c}\text { Hasil } \\
\text { Siklus I }\end{array}$ \\
\hline 1 & $\begin{array}{l}\text { Nilai rata-rata tes } \\
\text { formatif }\end{array}$ & 6,79 \\
2 & $\begin{array}{l}\text { Jumlah siswa yang } \\
3\end{array}$ & 26 \\
& $\begin{array}{l}\text { Presentase belajar ketuntasan } \\
\text { belajar }\end{array}$ & 68,2 \\
\hline
\end{tabular}


Dari tabel di atas dapat dijelaskan bahwa dengan menerapkan metode pembelajaran kooperatif model STAD diperoleh nilai rata-rata prestasi belajar siswa adalah 6,79 dan ketuntasan belajar mencapai $68,42 \%$ atau ada 26 siswa dari 38 siswa sudah tuntas belajar. Hasil tersebut menunjukkan bahwa pada siklus pertama secara klasikal siswa belum tuntas belajar, karena siswa yang memperoleh nilai $\geq 65$ hanya sebesar $68,42 \%$ lebih kecil dari persentase ketuntasan yang dikehendaki yaitu sebesar $85 \%$. Hal ini disebabkan karena siswa masih merasa baru dan belum mengerti apa yang dimaksudkan dan digunakan guru dengan menerapkan metode pembelajaran kooperatif model STAD.

Pelaksanaan kegiatan belajar mengajar pada siklus I ini masih terdapat kekurangan, sehingga perlu adanya revisi untuk dilakukan pada siklus berikutnya.

1. Guru perlu lebih terampil dalam memotivasi siswa dan lebih jelas dalam menyampaikan tujuan pembelajaran. Dimana siswa diajak untuk terlibat langsung dalam setiap kegiatan yang akan dilakukan.

2. Guru perlu mendistribusikan waktu secara baik dengan menambahkan informasiinformasi yang dirasa perlu dan memberi catatan.
3. Guru harus lebih terampil dan bersemangat dalam memotivasi siswa sehingga siswa bisa lebih antusias.

Pelaksanaan kegiatan belajar mengajar untuk siklus II dilaksanakan paa tanggal 18 Maret 2016 di kelas V SDN 167645 dengan jumlah siswa 38 siswa. Adapun data hasil penelitian pada siklus II adalah sebagai berikut:

Tabel 4.4 Pengelolaan Pembelajaran Pada Siklus II

\begin{tabular}{|c|c|c|c|c|}
\hline \multirow{2}{*}{ No } & \multirow{2}{*}{ Aspek yang diamati } & \multicolumn{2}{|c|}{ Penilaian } & \multirow{2}{*}{$\begin{array}{l}\text { Rata } \\
\text {-rata }\end{array}$} \\
\hline & & P1 & $\mathrm{P} 2$ & \\
\hline \multirow{3}{*}{ I } & 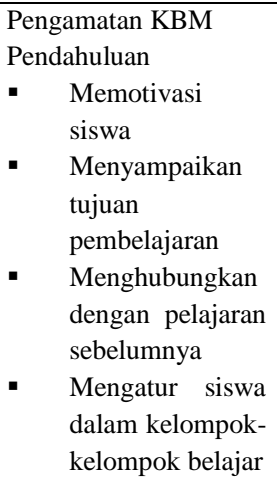 & $\begin{array}{l}3 \\
3\end{array}$ & $\begin{array}{l}3 \\
4\end{array}$ & $\begin{array}{c}3 \\
3,5\end{array}$ \\
\hline & $\begin{array}{l}\text { Kegiatan inti } \\
\text { - } \\
\text { Mempresentasika } \\
\mathrm{n} \text { langkah- } \\
\text { langkah metode } \\
\text { pembelajaran } \\
\text { kooperatif } \\
\text { Membimbing } \\
\text { siswa melakukan } \\
\text { kegiatan } \\
\text { Melatih } \\
\text { keterampilan } \\
\text { kooperatif } \\
\text { Mengawasi } \\
\text { setiap kelompok } \\
\text { secara bergiliran } \\
\text { Memberikan } \\
\text { bantuan kepada } \\
\text { kelompok yang } \\
\text { mengalami } \\
\text { kesulitan }\end{array}$ & $\begin{array}{l}4 \\
4\end{array}$ & $\begin{array}{l}4 \\
4 \\
4\end{array}$ & $\begin{array}{c}3,5 \\
4 \\
4 \\
4 \\
3\end{array}$ \\
\hline & $\begin{array}{lr}\text { Penutup } & \\
1 . & \text { Membimbing } \\
\text { siswa } & \text { membuat } \\
\text { rangkuman } & \end{array}$ & $\begin{array}{l}3 \\
4\end{array}$ & $\begin{array}{l}4 \\
4\end{array}$ & $\begin{array}{c}3,5 \\
4\end{array}$ \\
\hline
\end{tabular}




\begin{tabular}{|c|c|c|c|c|}
\hline & $\begin{array}{ll}2 . & \text { Memberikan } \\
\text { evaluasi }\end{array}$ & & & \\
\hline II & Pengelolaan Waktu & 3 & 3 & 2 \\
\hline III & \begin{tabular}{l}
\multicolumn{2}{l}{ Antusiasme Kelas } \\
$1 . \quad$ Siswa \\
antusias \\
$2 . \quad$ Guru antisias
\end{tabular} & $\begin{array}{l}4 \\
4\end{array}$ & $\begin{array}{l}3 \\
4\end{array}$ & $\begin{array}{c}3,5 \\
4\end{array}$ \\
\hline & Jumlah & $\begin{array}{l}4 \\
1\end{array}$ & 43 & 42 \\
\hline
\end{tabular}

Dari tabel di atas, tampak aspek-aspek yang diamati pada kegiatan belajar mengajar (siklus II) yang dilaksankan oleh guru dengan menerapkan metode pembelajaran kooperatif model STAD mendapatkan penilaian yang cukup baik dari pengamat. Namun demikian penilaian tesebut belum merupakan hasil yang optimal, untuk itu ada beberapa aspek yang perlu
Keterangan :

1) Tidak Baik

2) Cukup Baik

3)Kurang Baik

4) Baik

Tabel 4.5. Aktivitas Guru Dan Siswa Pada Siklus II

\begin{tabular}{|l|l|c|}
\hline No & Aktivitas Guru yang diamati & Presentase \\
\hline 1 & Menyampaikan tujuan & 6,7 \\
2 & Memotivasi siswa & 6,7 \\
3 & Mengkaitkan dengan pelajaran sebelumnya & 6,7 \\
4 & Menyampaikan materi/ langkah-langkah/ strategi & 11,7 \\
5 & Menjelaskan materi yang sulit & 11,7 \\
6 & Membimbing dan mengamati siswa dalam menemukan konsep & 25,0 \\
7 & Meminta siswa menyajikan dan mendiskusikan hasil kegiatan & 8,2 \\
8 & Memberikan umpan balik & 16,6 \\
9 & Membimbing siswa merangkum pelajaran & 6,7 \\
\hline No & Aktivitas siswa yang diamati & Presentase \\
\hline 1 & Mendengarkan/ memperhatikan penjelasan guru & 17,9 \\
2 & Membaca buku & 12,1 \\
3 & Bekerja dengan sesama anggota kelompok & 21,0 \\
4 & Diskusi antar siswa/ antara siswa dengan guru & 13,8 \\
5 & Menyajikan hasil pembelajaran & 4,6 \\
6 & Menyajikan/ menanggapi pertanyaan/ ide & 5,4 \\
7 & Menulis yang relevan dengan KBM & 7,7 \\
8 & Merangkum pembelajaran & 6,7 \\
9 & Mengerjakan tes evaluasi & 10,8 \\
\hline
\end{tabular}

Berdasarkan tabel I di atas, tampak bahwa aktifitas guru yang paling dominan pada siklus II adalah membimbing dan mengamati siswa mendapatkan perhatian untuk penyempurnaan penerapan pembelajaran selanjutnya. Aspekaspek tersebut adalah memotivasi siswa, membimbing siswa merumuskan kesimpulan/ menemukan konsep, dan pengelolaan waktu.

Berikut disajikan hasil observasi akivitas guru dan siswa: 
penurunan adalah memberi umpan balik/evaluasi/ Tanya jawab (16,6\%), menjelaskan materi yang sulit $(11,7)$. Meminta siswa mendiskusikan dan menyajikan hasil kegiatan $(8,2 \%)$, dan membimbing siswa merangkum pelajaran $(6,7 \%)$.

Sedangkan untuk aktivitas siswa yang paling dominan pada siklus II adalah bekerja dengan sesama anggota kelompok yaitu (21\%). Jika dibandingkan dengan siklus I, aktifitas ini mengalami peningkatan. Aktifitas siswa yang mengalami penurunan adalah mendengarkan/ memperhatikan penjelasan guru (17,9\%). Diskusi antar siswa/antara siswa dengan guru $(13,8 \%)$, menulis yang relevan dengan $\operatorname{KBM}(7,7 \%)$ dan merangkum pembelajaran $(6,7 \%)$.

Adapun aktifitas siswa yang mengalami peningkatan adalah membaca buku $(12,1 \%)$, menyajikan hasil pembelajaran (4,6\%), menanggapi/ mengajukan pertanyaan/ide $(5,4 \%), \quad$ dan mengerjakan tes evaluasi $(10,8 \%)$.

Berikutnya adalah rekapitulasi hasil tes formatif siswa terlihat pada tabel berikut :

Tabel 4.6. Rekapiltulasi Hasil Tes Formatif Siswa Pada Siklus II

\begin{tabular}{|l|l|c|}
\hline No & \multicolumn{1}{|c|}{ Uraian } & $\begin{array}{c}\text { Hasil } \\
\text { Siklus I }\end{array}$ \\
\hline 1 & $\begin{array}{l}\text { Nilai rata-rata tes } \\
\text { formatif }\end{array}$ & 7,29 \\
2 & $\begin{array}{l}\text { Jumlah siswa yang } \\
\text { tuntas belajar } \\
\text { Presentase ketuntasan } \\
\text { belajar }\end{array}$ & 31 \\
\hline
\end{tabular}

Dari tabel di atas diperoleh nilai rata-rata prestasi belajar siswa adalah 7,29 dan ketuntasan belajar mencapai $81,58 \%$ atau ada 31 siswa dari 38 siswa sudah tuntas belajar. Hasil ini menunjukkan bahwa pada siklus II ini ketuntasan belajar secara klasikal telah mengalami peningkatan sedikit lebih baik dari siklus I.

Adanya peningkatan hasil belajar siswa ini karena setelah guru menginformasikan bahwa setiap akhir pelajaran akan selalu diadakan tes sehingga pada pertemuan berikutnya siswa lebih termotivasi untuk belajar.

Selain itu siswa juga sudah mulai mengerti apa yang dimaksudkan dan diinginkan guru dengan menerapkan metode pembelajarn kooperatif model STAD. Pelaksanan kegiatan belajar pada Siklus II ini masih terdapat kekurangan-kekurangan. Maka perlu adanya revisi untuk dilaksanakan pada siklus II antara lain :

1. Guru harus lebih dekat dengan siswa sehingga tidak ada perasaan takut dalam diri siswa baik untuk mengemukakan pendapat atau bertanya.

2. Guru harus lebih sabar dalam membimbing siswa merumuskan kesimpulan/menemukan konsep.

3. Guru harus mendistribusikan waktu secaraa baik sehingga kegiatan pembelajaran dapat berjalan sesuai dengan yang diharapkan.

4. Guru sebaiknya menambah lebih banyak contoh soal dan meberi 
soal-soal-soal latihan pada siswa untuk dikerjakan pada setiap kegiatan belajar mengajar.

Pelaksanaan kegiatan belajar mengajar untuk siklus III dilaksanakan pada tanggal 28 Maret 2016 di kelas V SDN 167645 dengan jumlah siswa 38 siswa.

Adapun data hasil penelitian pada siklus III adalah sebagai berikut:

Tabel 4.7. Pengelolaan Pembelajaran Pada Siklus II

\begin{tabular}{|c|c|c|c|c|}
\hline \multirow{2}{*}{ No } & \multirow{2}{*}{ Aspek yang diamati } & \multicolumn{2}{|c|}{ Penilaian } & \multirow{2}{*}{$\begin{array}{l}\text { Rata- } \\
\text { rata }\end{array}$} \\
\hline & & P1 & $\mathrm{P} 2$ & \\
\hline \multirow{3}{*}{$\mathrm{I}$} & $\begin{array}{l}\text { Pengamatan KBM } \\
\text { A. Pendahuluan } \\
\text { 1. Memotivasi siswa } \\
\text { 2. Menyampaikan tujuan pembelajaran } \\
\text { 3. Menghubungkan dengan pelajaran sebelumnya } \\
\text { 4. Mengatur siswa dalam kelompok-kelompok belajar }\end{array}$ & $\begin{array}{l}3 \\
4\end{array}$ & $\begin{array}{l}3 \\
4\end{array}$ & $\begin{array}{l}3 \\
4\end{array}$ \\
\hline & $\begin{array}{l}\text { B. Kegiatan inti } \\
\text { 1. Mempresentasikan langkah metode pembelajaran } \\
\text { kooperatif } \\
\text { 2. Membimbing siswa melakukan kegiatan } \\
\text { 3. Melatih keterampilan kooperatif } \\
\text { 4. Mengawasi setiap kelompok secara bergiliran } \\
\text { 5. Memberikan bantuan kepada kelompok yang } \\
\text { mengalami kesulitan }\end{array}$ & $\begin{array}{l}4 \\
4 \\
4\end{array}$ & $\begin{array}{l}4 \\
4 \\
4\end{array}$ & $\begin{array}{l}4 \\
4 \\
4 \\
3,5\end{array}$ \\
\hline & $\begin{array}{l}\text { C. } \\
\text { Penutup } \\
\text { 1. } \quad \text { Membimbing siswa membuat rangkuman } \\
\text { 2. } \quad \text { Memberikan evaluasi }\end{array}$ & $\begin{array}{l}4 \\
4\end{array}$ & $\begin{array}{l}4 \\
4\end{array}$ & $\begin{array}{l}4 \\
4\end{array}$ \\
\hline II & Pengelolaan Waktu & 3 & 3 & 3 \\
\hline III & $\begin{array}{l}\text { Antusiasme Kelas } \\
\text { 1. } \quad \text { Siswa antusia } \\
\text { 2. } \quad \text { Guru antisias }\end{array}$ & $\begin{array}{l}4 \\
4\end{array}$ & $\begin{array}{l}4 \\
4\end{array}$ & $\begin{array}{l}4 \\
4\end{array}$ \\
\hline & Jumlah & 45 & 44 & 44,5 \\
\hline
\end{tabular}

Keterangan : Nilai : Kriteria

1) : Tidak Baik

2) : Kurang Baik

3) : Cukup Baik

4) : Baik

Dari tabel di atas, dapat dilihat aspek-aspek yang diamati pada kegiatan belajar mengajar (siklus III) yang dilaksanakan oleh guru dengan menerapkan metode pembelajaran kooperatif model STAD mendapatkan penilaian cukup baik dari pengamat adalah memotivasi siswa, membimbing siswa merumuskan kesimpulan/ menemukan konsep, dan pengelolaan waktu.

Penyempurnaan aspek-aspek diatas dalam menerapkan metode pembelajaran kooperatif model 
STAD diharapkan dapat berhasil semaksimal mungkin.

Tabel 4.8. Aktivitas Guru dan Siswa Pada Siklus III

\begin{tabular}{|l|l|c|}
\hline No & Aktivitas Guru yang diamati & Persentase \\
\hline 1 & Menyampaikan tujuan & 6,7 \\
2 & Memotivasi siswa & 6,7 \\
3 & Mengkaitkan dengan pelajaran sebelumnya & 10,7 \\
4 & Menyampaikan materi/ langkah-langkah/ strategi & 13,3 \\
5 & Menjelaskan materi yang sulit & 10,0 \\
6 & Membimbing dan mengamati siswa dalam menemukan konsep & 22,6 \\
7 & Meminta siswa menyajikan dan mendiskusikan hasil kegiatan & 10,0 \\
8 & Memberikan umpan balik & 11,7 \\
9 & Membimbing siswa merangkum pelajaran & 10,0 \\
\hline No & Aktivitas siswa yang diamati & Persentase \\
\hline 1 & Mendengarkan/ memperhatikan penjelasan guru & 20,8 \\
2 & Membaca buku & 13,1 \\
3 & Bekerja dengan sesama anggota kelompok & 22,1 \\
4 & Diskusi antar siswa/ antara siswa dengan guru & 15,0 \\
5 & Menyajikan hasil pembelajaran & 2,9 \\
6 & Menyajikan/ menanggapi pertanyaan/ ide & 4,2 \\
7 & Menulis yang relevan dengan KBM & 6,1 \\
8 & Merangkum pembelajaran & 7,3 \\
9 & Mengerjakan tes evaluasi & 8,5 \\
\hline
\end{tabular}

Berdasarkan tabel di atas tampak bahwa aktivitas guru yang paling dominan pada siklus III adalah membimbing dan mengamati siswa dalam menemukan konsep yaitu 22,6\%, sedangkan aktivitas menjelaskan materi yang sulit dan memberi umpan balik/evaluasi/tanya jawab menurun masing-masing sebesar (10\%), dan (11,7\%). Aktivitas lain yang mengalami peningkatan adalah mengkaitkan dengan pelajaran sebelumnya (10\%), menyampiakan materi/strategi /langkah-langkah (13,3\%), meminta siswa menyajikan dan mendiskusikan hasil kegiatan (10\%), dan membimbing siswa merangkum pelajaran (10\%). Adapun aktivitas yang tidak mengalami perubahan adalah menyampaikan tujuan $(6,7 \%)$ dan memotivasi siswa $(6,7 \%)$.

Sedangkan untuk aktivitas siswa yang paling dominan pada siklus III adalah bekerja dengan sesama anggota kelompok yaitu $(22,1 \%)$ dan mendengarkan/ memperhatikan penjelasan guru (20,8\%), aktivitas yang mengalami peningkatan adalah membaca buku siswa $(13,1 \%)$ dan diskusi antar siswa/antara siswa dengan guru $(15,0 \%)$. Sedangkan aktivitas yang lainnya mengalami penurunan. Berikut adalah rekapitulasi hasil tes 
formatif siswa seperti terlihat pada tabel berikut.

Tabel 4.9. Rekapiltulasi Hasil Tes Formatif Siswa Pada Siklus II

\begin{tabular}{|l|l|l|}
\hline No & Uraian & $\begin{array}{l}\text { Hasil } \\
\text { Siklus III }\end{array}$ \\
\hline & $\begin{array}{l}\text { Nilai rata-rata } \\
\text { tes formatif }\end{array}$ & \\
1 & Jumlah siswa & 7,97 \\
2 & yang tuntas & 36 \\
3 & $\begin{array}{l}\text { belajar } \\
\text { Presentase } \\
\text { ketuntasan } \\
\text { belajar }\end{array}$ & 94,74 \\
\hline
\end{tabular}

Berdasarkan tabel di atas diperoleh nilai rata-rata tes formatif sebesar 7,97 dan dari 38 siswa yang telah tuntas sebanyak 36 siswa dan 2 siswa belum mencapai ketuntasan belajar. Maka secara klasikal ketuntasan belajar yang telah tercapai sebesar 94,74\% (termasuk kategori tuntas). Hasil pada siklus III ini mengalami peningkatan lebih baik dari siklus II.

Melalui hasil penelitian ini menunjukkan bahwa metode pembelajaran kooperatif model STAD memiliki dampak positif dalam meningkatkan prestasi belajar siswa. Hal ini dapat dilihat dari semakin mantapnya pemahaman siswa terhadap materi yang disampaikan guru (ketuntasan belajar meningkat dari siklus I, II, dan III) yaitu masing-masing 68,2\%, 81,58\% dan $94,74 \%$. Pada siklus III ketuntasan belajar siswa secara klasikal telah tercapai. Sedangkan kelompok yang mendapatkan penghargaan adalah kelompok I dengan nilai kelompok tertinggi sebesar 6,17.

\section{SIMPULAN}

Berdasarkan hasil penelitian yang telah dipaparkan dapat disimpulkan sebagai berikut :

1) Metode pembelajaran kooperatif model STAD memiliki dampak positif dalam meningkatkan prestasi belajar siswa yang ditandai dengan peningkatan ketuntasan belajar siswa dalam setiap siklus, yaitu siklus I $(68,42 \%)$, siklus II $(81,58 \%)$, siklus III $(94,74 \%)$.

2) Siswa dapat bekerja secara mandiri maupun kelompok, serta mampu mempertanggung jawabkan tugas individu maupun kelompok.

\section{DAFTAR RUJUKAN}

Arikunto, Suharsimi. 2006. Dasardasar Evaluasi Pendidikan. Jakarta: Bumi Aksara.

Arikunto, Suharsimi. 2006. Prosedur Penelitian Suatu Pendekatan Praktek. Jakarta: Rineksa Cipta.

Nur, Moh. 2008. Pemotivasian Siswa Untuk Belajar. Surabaya. University Press Universitas Negeri Srabaya. 
Asmalia Pane: Upaya Meningkatkan Prestasi ...

Nur, Muhammad. 2009.

Pembelajaran Kooperatif.

Surabaya University Negeri.

Riduwan. 2012 belajar Mudah

Penelitian Untuk Guru-

Karyawan dan Peneliti

Pemula. Bandung: Alfabeta.

Sukmadinata, Nana Syaodih. 2012. Metode Penelitian

Pendidikan. Bandung: PT.

Remaja Rosdakarya. 